\title{
INVESTIGATIONS OF RESISTANCE TO SEIZING OF LASER-TEXTURED ELEMENTS
}

\author{
Bogdan Antoszewski \\ Dr., Professor \\ Kielce University of Technology, Center for Laser Technology of Metals (Kielce, Poland) \\ ORCID: 0000-0002-5675-478X \\ b.antoszewski@tu.kielce.pl
}

The paper presents results of experiments concerning the assessment of the texture effect on scuffing resistance. The results showed that texturing causes an increase in scuffing resistance. In addition, textures showing lower surface energy and having higher volume were found to form surfaces more resistant to scuffing.

Keywords: scuffing, texturing, laser micromachining.

DOI: https://doi.org/10.32845/msnau.2019.4.1

\section{Introduction}

The term 'scuffing' describes sudden damage and failure in friction pair. It results from a series of phenomena occurring in friction pair and causing irregular fluctuations of friction force. The reasons for changes in friction force can be of different character, but that of adhesive nature is the most frequent and are connected with the approach of surfaces interacting due to the action of external forces [1]. Adhesive bonds are to be treated as a physical phenomenon of combining materials of friction pair through the original division boundary. Mutual solubility of metals, type of metallic bonds and power phenomena, e.g. exceeding the potential energy barrier caused by the action of force, heat or passage of current, are of importance here. The intensity of scuffing is also affected by such factors as a dynamic increase in temperature or changes in the kinetics of friction pair. These factors show that scuffing is a very complex process $[1,3]$.

The presence of a stable layer of oil film or of a boundary layer separating the mating elements of friction pair is one of the most effective ways of preventing the escalation of adhesive forces . It can be achieved by a suitable choice of lubricating agent providing stable boundary layers or by a proper preparation of the construction of friction pair $[7,8,9,10,11]$. The paper aims at assessing the effect of texturing on scuffing resistance together with changes in surface energy caused by this texturing.

Modern technologies, especially those providing the effect of concentrated energy flux on materials, make it possible to shape a material on a micron scale. Considering the shaping of the surface, such a process is called surface structuring. Texture is one of the characteristic surface structures. Surfaces containing separated regular areas which can be described by geometrical, physicomechanical or physicochemical parameters, unlike the rest of the layer, can be treated as surfa ces with texture [2]. Areas forming texture result from the use of technology or materials different from those used for the rest of the surface. Conditions of lubrication are improved by the presence of texture in a natural way because irregularities of surface, especially regular cavities, make containers of lubricant. It can be used when lubricant supply disruptions occur. Moreover, as shown in a number of papers $[4,5,6]$ under certain conditions of load properly shaped textures can generate an additional aerodynamic lift, which makes the operational range of parameters of friction pair wider.

Texture changes the surface energy value of an element. Therefore, wherever high adhesion of liquid to the surface is necessary procedur es decreasing surface energy are used, e.g. in printing industry the texturing of surfaces of printing rollers makes the distribution of printing ink as well as the distribution of a lubricating agent in friction pairs under lubrication easier $[9,10,11]$. It can then be concluded that texture, surface energy and lubrication are closely related. Thus, the recognition of the dependence of the effect of texture parameters and changes of surface energy accompanying them on the course of scuffing is the import ant problem to be solved.

Materials and methods

Investigations of scuffing resistance for samples with textured surface were carried out under the conditions of friction with paraffin oil lubrication done by a Falex T-09- type tribological tester.

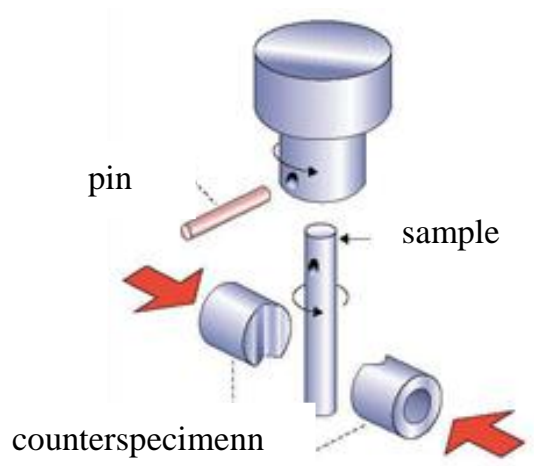

Fig.1 Diagram of friction pair in a Falex T-05-type tribological tester

The friction pair in the tester (Fig.1) consists of a sample in the form of a roller made of $40 \mathrm{H}$ steel which is attached to the drive shaft by a copper pin and clasped by two counterspecimen in the form of prismatic blocks placed in the arms of the head lever. 

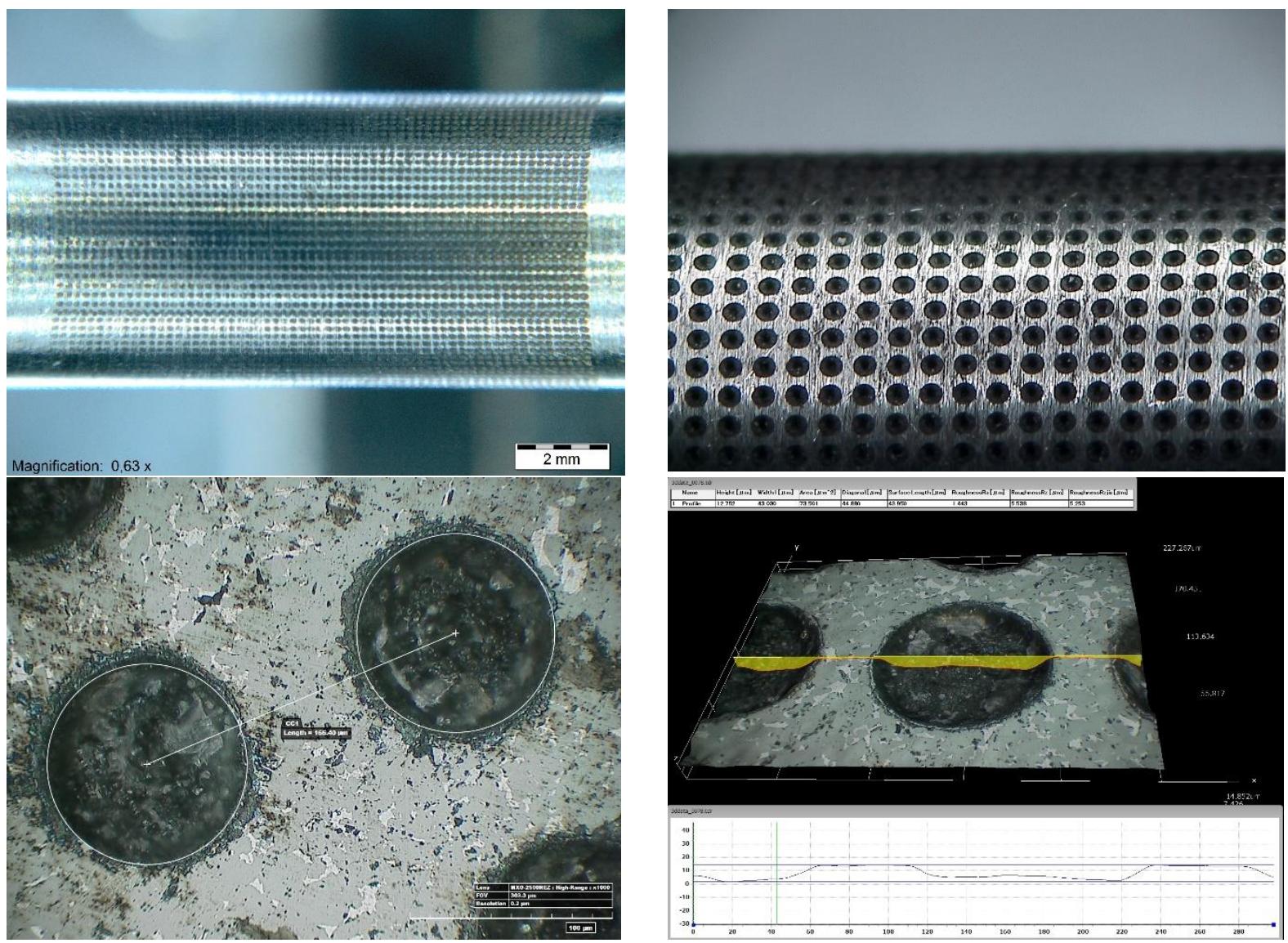

Fig. 2 View of the fragment of the report documenting textures carried out on the tang of the testing mach

During the investigation a gradual increase in the tension force of springs which load the head lever. Prismatic blocks in them clamp with a higher and higher force on the sample rotating at the constant speed of 290 r.p.m. The result of the investigations consists in giving friction resistance which is the value of a force at which the copper pin is sheared, whereas in the absence of scuffing the highest load value of samples occurs. The course of the test is controlled by a computer which records the course of load and friction force in the time function.

Table 1 Putting together of parameters tangs (of samples) applied in examinations

\begin{tabular}{|c|c|c|c|c|c|}
\hline $\begin{array}{c}\text { No. } \\
\text { Sample }\end{array}$ & $\begin{array}{c}\text { Diameter cavities / depth } \\
{[\mu \mathrm{m}]}\end{array}$ & $\begin{array}{c}\text { Distance cavities } \\
{[\mu \mathrm{m}]}\end{array}$ & $\begin{array}{c}\text { Blackening degree } \\
{[\%]}\end{array}$ & $\begin{array}{c}\text { Surface energy } \\
{\left[\mathrm{mJ}^{2} \mathrm{~cm}^{2}\right]}\end{array}$ & $\begin{array}{c}\text { The volume of the cavities one / all } \\
10^{-3} \times \mathrm{mm}^{3}\end{array}$ \\
\hline 1 & $140 / 15$ & 190 & 41 & 56,7 & $0,23 / 1081,6$ \\
\hline 2 & $100 / 15$ & 180 & 25 & 60,9 & $0,117 / 707$ \\
\hline 3 & $80 / 15$ & 165 & 18 & 63,6 & $0.075 / 747$ \\
\hline
\end{tabular}

Specials samples, steel $40 \mathrm{H}$ arbors exposed to heat treatment up to the hardness of $45 \mathrm{HRC}$, were prepared for experiments . Next, arbors underwent laser texturing $[2,7,8]$. For texturing a TruMicro $5235 \mathrm{c}$ impulse laser emitting the radiation of the wave-length of $343 \mathrm{~nm}$ with galvo optics (SCANLAB SFO 6000 with lens of the focal length of $160 \mathrm{~mm}$ ) was used. The following parameters of the process: mean power of $5 \mathrm{~W}, 400 \mathrm{kHZ}$ frequency, impulse time of $6.2 \mathrm{ps}$, band advance rate of 100 $\mathrm{mm} / \mathrm{s}$ were considered. The HATCH PARALLEL procedure with a decreasing diameter was repeatedly used to obtain individual cavities. A definite series of cavities was made on the side surface of the roll, and, then, the revolution of the arbor at a given angle followed, and the cycle was repeated until the complete circuit of the arbor was fulfilled. The shape of cavities and their ge- ometrical parameters were determined on the basis of measurements taken using a HIROX KH - 8700 microscope. Fig. 2 gives a model report being evidence of textures made on the tester

The value of free surface energy of construction al materials is determined in the intermediate way using the measurement of wetting angles with selected testing liquids. As testing liquids distilled water and diiodomethane were used to measure the wetting angle. The following values of constans of free surface energy of testing liquid and its polar and u-mode components were taken: $\gamma_{\mathrm{w}}=72.8\left[\mathrm{~mJ} / \mathrm{m}^{2}\right], \gamma^{p_{w}}=51.0\left[\mathrm{~mJ} / \mathrm{m}^{2}\right], \gamma^{d}{ }_{w}=21.8$ $\left[\mathrm{mJ} / \mathrm{m}^{2}\right], \gamma_{d}=50.8\left[\mathrm{~mJ} / \mathrm{m}^{2}\right], \gamma^{p_{d}}=2.3\left[\mathrm{~mJ} / \mathrm{m}^{2}\right], \gamma_{d}^{d_{d}}=48.5\left[\mathrm{~mJ} / \mathrm{m}^{2}\right] . A$ micropipette of $5 \mu \mathrm{l}$ constant volume was used to put testing liquid on the surface under investigation 
One of the most popular methods of determining free surface energy is that by Owens - Wendt[19, 20] in which free surface energy is treated as a sum of two components: u-mode and polar:

$$
\gamma_{s}=\gamma_{s}^{d}+\gamma_{s}^{p}
$$

where: $\gamma^{d} s$-u-mode component of free surface energy, $\gamma^{p} s$ - polar component of free surface energy.

$$
\begin{gathered}
\left(\gamma_{s}^{d}\right)^{0,5}=\frac{\gamma_{d}\left(\cos \Theta_{d}+1\right)-\sqrt{\frac{\gamma_{d}^{p}}{\gamma_{w}^{p}}} \gamma_{w}\left(\cos \Theta_{w}+1\right)}{2\left(\sqrt{\gamma_{d}^{d}}-\sqrt{\gamma_{d}^{p} \frac{\gamma_{w}^{d}}{\gamma_{w}^{p}}}\right)} \\
\left(\gamma_{s}^{p}\right)^{0,5}=\frac{\gamma_{w}\left(\cos \Theta_{w}+1\right)-2 \sqrt{\gamma_{s}^{d} \gamma_{w}^{d}}}{2 \sqrt{\gamma_{w}^{p}}}
\end{gathered}
$$

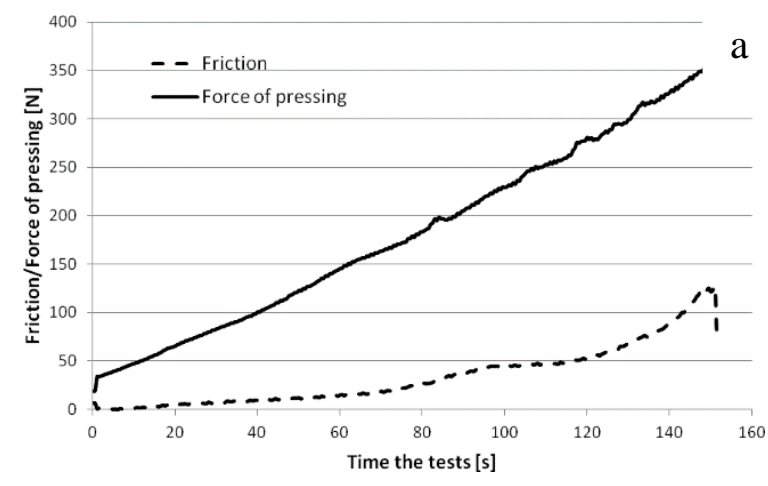

Fig. 3 a) model course of the experimental run, b) results of investigations of scuffing resistance

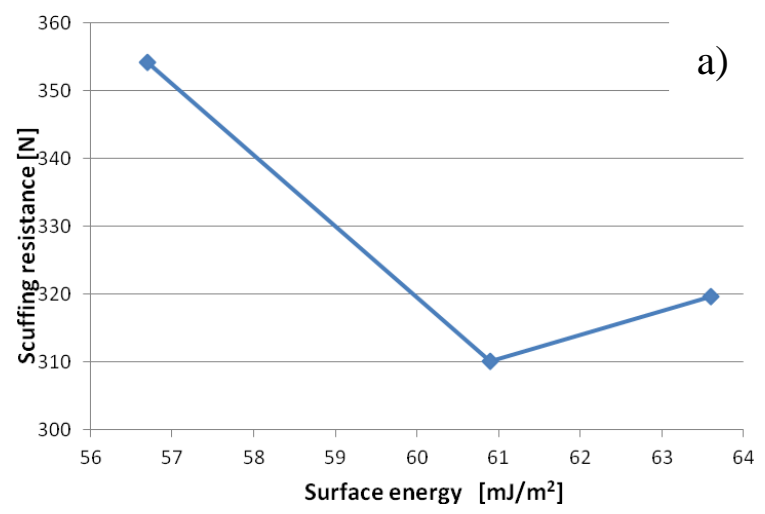

Fig. 4 Dependence of scuffing resistance on a) surface energy b) volume of texture cavities

According to the list of results given in Fig. $3 \mathrm{~b}$ and Table 1 , an increase in scuffing force is accompanied by an increase in the blackening degree of the surface. Considering the results shown in graphs in Figs $4 \mathrm{a}$ and $4 \mathrm{~b}$ scuffing resistance was found to decrease with an increase in surface energy but to increase when the volume of cavities increases. An excess of the energy barrier of linkage by these samples accounts for a decrease in the value of scuffing force for samples of higher energy state (lower degree of blackening) [1],[3]. An increase in oil volume in cavities can imply the appearance of hydrodynamic effects preventing the formation of adhesive bonds, which increases scuffing resistance. The effect of the volume of cavities on scuffing resistance will be investigated In more detail In the experiments
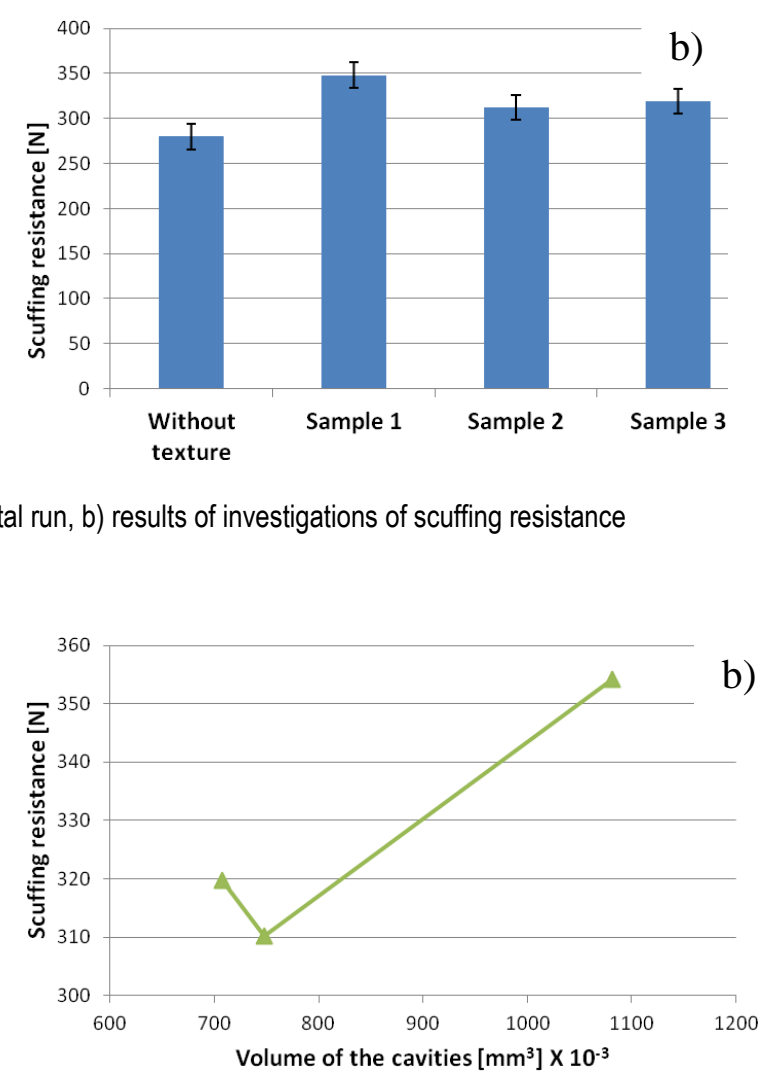

where: $\gamma_{d}-$ free surface energy of diiodomethane, $\gamma^{d}-$ u-mode component of free surface energy of diiodomethane, $Y^{p_{d}}$ - polar component of free surface energy of diiodomethane, $\gamma_{w}-$ free surface energy of water, $\gamma^{d} w-u$-mode component of free surface energy of water, $\gamma^{p_{w}}$ - polar component of free surface energy of water, $\Theta_{d}$ - angle wetted with diiodomethane, $\Theta_{w}-$ angle wetted with water. The results obtained are given in Table 1.

\section{Results and discussion}

The results of measurements of contact force at which scuffing occurred (scuffing force) every time was related to the result obtained for samples without texturing. Values obtained as a mean of three measurements were considered in the analysis. Fig. 3a shows a model course of the experimental run whereas the diagram gives a list of mean values of scuffing force.

to come. The effect of the depth of an individual element of texture will be given particular attention in them. It is to be stressed that the results obtained refer to the contact lubricated with paraffin oil which does not react with the surface and does not form stable boundary layers.

\section{Conclusions}

Considering the results presented, the following conclusions can be drawn:

1. In friction pairs lubricated with paraffin oil texturing increases scuffing resistance ; the value of scuffing force increase was from 43 to $59 \%$ in the investigations presented here.

2. The higher the scuffing resistance of friction pairs under texturing, the lower the surface energy. 3. An increase in the volume of texture cavities increases scuffing resistance. 


\section{References}

1. D.Markov, D.Kelly, Mechanism of adhesion-initiated catastrophic wear; pure sliding, Wear vol. 239,2000, pp.189-210. 10 pages

2. B.Antoszewski, P. Sęk, Laser surface texturing: chosen problems, SPIE Proceedings Vol. 8703 Published 22.01.2013;

3. Ł.Wojciechowski, S.Nosal, The application of free surface energy measurement to valuation of adhesive scuffing, Maintenance and Reliability $\mathrm{nr}$ 2/2010, pp.83-90

4. B.Antoszewski , V.Tarelnik, Mechanical seals with sliding surface texture - model fluid flow and some aspects of the laser forming of the texture, Procedia Engineering 39 (2012) 51-62

5. B.Antoszewski, Production, properties and application of laser textured components, Logistyka Nr 6, s. 88-100 2009

6. B. Antoszewski, Surface texture formation in process of Nd:YAG laser, Zeszyty Naukowe Politechniki Świętokrzyskiej Seria Nauki Techniczne Elektryka Z nr 152011

7. N. Radek, B.Antoszewski, Influence of laser treatment on the properties of electro-spark deposited coatings, Kovove Materialy-Metallic Materials 47 (2009) (1) 31-38.

8.. Tarelnyk V., Konoplianchenko I., Martsynkovskyy V., Zhukov A., Kurp P. (2019) Comparative Tribological Tests for Face Impulse Seals Sliding Surfaces Formed by Various Methods. In: Ivanov V. et al. (eds) Advances in Design, Simulation and Manufacturing. DSMIE 2018. Lecture Notes in Mechanical Engineering. Springer, Cham https://doi.org/10.1007/978-3-319-93587-4_40

Антошевський Б., Кєлецький технічий університет (Польща)

Дослідження стійкості до стирання елементів лазерної текстури

У статті представлені результати експериментів по оцінці впливу текстури на опір стиранню. Результати показали, що текстурування викликає збільшення опору стиранню. Крім того, було виявлено, що текстури з меншою поверхневою енергією та такі, що мають більший об’єм, формують поверхні, більш стійкі до стирання.

Ключові слова: стирання, текстурування, лазерна мікрообробка.

Дата надходження до редакції: 16.09.2019 